\title{
The Libyan Revolution: Philosophical Interpretations
}

\author{
Godwin Okaneme \\ Department of Philosophy and Religion, University of Abuja, Abuja, Nigeria \\ Email: godack76@yahoo.com
}

Received 1 January 2015; accepted 17 January 2015; published 21 January 2015

Copyright (C) 2015 by author and Scientific Research Publishing Inc.

This work is licensed under the Creative Commons Attribution International License (CC BY). http://creativecommons.org/licenses/by/4.0/

(c) (i) Open Access

\begin{abstract}
Libya, one of the notable African countries was engulfed in political crisis in February 2011. The protests were targeted towards the draconian rule of one of Africa's longest reigning despots, Muammar Gaddafi who ruled Libya for forty two years without showing any sign of relinquishing power until the avoidable bloody uprisings eventually claimed his life. This paper chronicles the Libyan revolution and $\mathrm{X}$-rays its philosophical importance. It is of the strong view that the greatest political challenge facing many African countries today (including Libya) is the inability of its political leaders to see politics as an opportunity to render selfless service to the masses through political governance. This singularly accounts for the reason behind so many unfortunate dictatorial tendencies in governance in some of these African countries. The issue of sit-tightism in office as aptly exemplified by Gaddafi is indeed a worrisome development not only to Libya but also to some other African countries that share the same unfortunate and better forgotten political experience with her. The paper strongly believes that the Libyan revolution should indeed serve as a serious warning signal to other African leaders who share Gaddafi's retrogressive leadership philosophy of holding tenaciously to power to the detriment of their countries and their helpless citizens whom they hold in brazen perpetual political captivity.
\end{abstract}

\section{Keywords}

Revolution, Philosophical, Interpretations, Libya, Crisis

\section{Introduction}

The 2011 Libyan Civil War which is popularly referred to as the Libyan revolution was an armed struggle and conflict in the North African state of Libyan which was fought between forces loyal to Colonel Muammar Gaddafi and those that sought to oust his government. The war was preceded by orchestrated protests in Benghazi 
which began on 15 February 2011, which led to clashes with security forces that fired on the crowd that gathered in the city.

The protests later escalated into a full-blown rebellion that spread across the entire length and breadth of the country, with the forces opposing Gaddafi establishing an organized front, an interim governing body known as the National Transitional Council (NTC). On 16 September 2011, the National Transitional Council was recognized by the United Nations as the sole legal representative of the Libyan nation, thus replacing the Gaddafi government. This singular action by the United Nations sent a clear message to Gaddafi and his cohorts that their days in power were actually numbered and that they were indeed living on borrowed times.

The United Nations Security Council passed an initial resolution precisely on 26 February, 2011 freezing the assets of Gaddafi and his inner circles, restricted their movement and also referred the matter to the International Criminal Court at the Hague for investigation. These developments seemed to have taken Gaddafi and his allies by surprise, little wonder, they regrouped and in early March, his forces rallied, pushed eastwards and re-took several coastal cities before finally attacking Benghazi. In furtherance of its ruthlessness against Gaddafi and his allies, the United Nations further resolved and authorized member states to establish and strictly enforce a no-fly zone over Libya. In response to this onslaught, the Gaddafi government announced a ceasefire which unfortunately, it failed to uphold. In August, rebel forces engaged forces loyal to Gaddafi in a fierce coastal offensive and recaptured most of the territories they had lost earlier and eventually captured Tripoli, the capital City of Libya. The revolution eventually came to a climax on 20 October 2011 when Gaddafi was captured and killed in Sirte while he was trying to escape from the forces of the National Transitional Council (NTC).

\section{A Brief Excursion into the World of Philosophy}

Philosophy from time immemorial has been a very curious discipline. It is indeed a puzzling enterprise both to the lettered and the unlettered. The question that readily comes to mind then is what is philosophy? According to the Penguin Dictionary of Philosophy (Mautner, 2000: 422-423) the term philosophy is used in a variety of senses. Philosophy as an intellectual activity can be variously defined, depending on whether the emphasis is placed on its method, its subject matter or its purpose.

Olusegun Oladipo, a notable Nigerian philosophy scholar in his incisive and scholarly essay titled "On philosophy" elaborates on the primary purpose and uncommon importance of philosophy. According to him, "The primary purpose of this essay is to provide an insight into the nature of philosophy not only as an academic discipline but more importantly as an aspect of the general human (intellectual) endeavour to acquire self-knowledge that is knowledge of the human person in relation to the environment in which hr activities take place. The primary reason for doing this in this context is to underscore the importance of philosophy as a means of stimulating people to think about the basic problems of existence both in their universal and particularistic manifestation. Philosophy, it is emphasized is nothing unless it permits the kind of self-examination that enable persons-as individuals and as social collectives to look into themselves and affect their environments in positive ways (Oladipo, 2007: 13).

Onigbinde (2006: 1) puts the issue of the definition in another perspective. According to him, the word philosophy is not easy to define, even though it belongs to everyday language. Yet, if we are going to understand what someone means by it, we do not require a definition. Nevertheless, even though the term "philosophy" is one with which we already have some familiarity, it is not a simple non-controversial matter. This may tend to startle the reader but some explanations would clear the fog of confusion that may be created by the non-precision nature of our subject-matter.

Speaking further on the role of philosophy in human affairs, Onigbinde (2009: 1) opined that most people probably have never bothered to know how philosophy can and does touch their lives. Some simple examples may help to show some connections between philosophy and human life. When someone in anger, blames the world for his misfortunes, he states unconsciously, basic belief. When someone declares his love of life, in some joyous moments, he too expresses a view of the world in general. Of course, statements like these need not to be final as they might later be modified or totally abandoned.

In his own analysis, Harrison-Barbet (1990: 1) asserted that: The question "what is philosophy?" unlike the apparently similar questions "what is history" and "what is science?" does not admit of a straight forward answer. Indeed it would not be too much of an exaggeration to say, paradoxically, that the question is itself philosophical one in so far as different philosophers tend to have different conceptions as to the nature of their cho- 
sen discipline.

Philosophy comes from two Greek words-philos and Sophia which literarily means love of wisdom. Philosophy is a study that seeks to understand the mysteries of existence and reality. It tries to discover the exact nature of truth and knowledge and to find what is of basic value and importance in life. It equally examines the relationship between humanity and nature as well as that between the individual and the society.

The term philosophy cannot be defined precisely because it is so complex as well as controversial. Different philosophers have different views of the nature, methods and range of philosophy. Philosophy has enormous influence on the daily lives of people. Daily decisions taken by human beings involve Philosophical decisions which help to shape and reshape human destiny.

\section{Libya: A Historical Sketch}

The history of Libya includes the history of its rich mix of ethnic groups added to the indigenous Berber tribes. Berbers, the bulk of Libya's population, have been present through the entire history of the country. For most of its history, Libya has been subjected to varying degrees of foreign control, from Europe, Asia and Africa. The modern history of independent Libya began in 1951 (cf: Wikipedia Encyclopedia available at http://www.wikipedia.com/nigeria).

Before attaining independent status in 1951, Libya was under the control of other nations including the Roman, Spanish, Italian, French and British Empires. On 21 November 1949, the United Nations General Assembly passed a resolution stating that Libya should become independent before 1 January 1952. On 24 December 1951, Libya declared its independence with representatives of the three major regions that make up the country namely: Cyrenaica, Tripolitania and Fezzan declaring a Union which culminated in the country being called the United Kingdom of Libya. At its inception, the new country had a Federal Government with the three sates of Cyrenaica, Tripolitania and Fezzan being autonomous. The kingdom also had three capital cities namely: Tripoli, Benghazi and Bayda. When Libya achieved its independence in 1951, it became the first African country to achieve political independence through the United Nations. Libya was faced with some challenges when it achieved independent status. The country had no colleges and had just few college graduates. This meant in essence that the nation lacked requisite manpower. Equally disturbing was the fact that many of its citizens were not literate.

The nation of Libya had rich oil deposits and the first oil field was discovered in the country in 1959, while it began oil exportation in 1963. The federal system of government was changed in 1963 to reflect the name of the nation—-kingdom of Libya—which depicted a monarchial set up.

The monarchical rule in Libya came to an end on 1 September 1969 when a group of young, overzealous and enthusiastic military officers led by Muammar Al-Gaddafi staged a coup d'état against the ruling monarch then, king Idris 1 while he was away to Turkey for medical treatment. As a result of the success of the military intervention, the country was renamed the Libyan Arab republic.

\section{Gaddafi and the Remaking of Libya}

On 1 September 1969, Muammar Gaddafi staged a bloodless military coup in Libya at the age of 27, thus making him one of the youngest rulers in world history at that time. His coup toppled the monarchical rule of king Idris 1 who had been in the political saddle of Libya since its independence in 1951. After the bloodless coup, Gaddafi established the Libyan Revolutionary Command Council (RCC) headed by himself and abolished the monarchy and the old constitution and proclaimed the new Libyan Arab Republic with the Motto "Freedom, socialism and unity" (cf: www.Globaledge.com available at http://globaledge.msu.edu).

On coming to power in 1969, Gaddafi's government under the Revolutionary Command Council initiated some reforms especially in the education, health and housing sectors for the entire citizenry. His reforms, though not entirely effective, had their effect on the lives of Libyan citizens. Public education in the country became free and primary education became compulsory for both boys and girls. Medical care was also available to the public at no cost at all but providing housing for all is a task Gaddafi's government was not able to accomplish effectively before his eventual ouster from power (cf: Housing. www.Encyclopaedia Britannica, available at http://www.britannica.com).

Under Gaddafi's long reign, Libyan economy improved tremendously and that literarily translated to increased standard of living for many Libyan citizens. Under Gaddafi, per capita income in the country rose to 
more than 11,000 US dollars, the fifth highest in Africa (cf: "African countries by GDP per capita > GDP per Capital (Most Recent) by Country", Nation Master, available at http://www.nationmaster.com). The increase in prosperity which came about as a result of the increased oil revenue accruing to the country was unfortunately accompanied by a controversial foreign policy and also increased political reprehension and agitation at home. Official corruption perpetrated by Gaddafi and his cohorts who looted the wealth of Libya with brazen impunity helped in no small way to derail the growth of the Libyan economy.

One of the worst controversies that surrounded Libya as a country throughout the long reign of Gaddafi was the frequent change of the country's name. Indeed Libya's name was changed several times during Gaddafi's tenure. At first, the name was the Libyan Arab Republic. This took place immediately Gaddafi took over the leadership of the country in a bloodless coup in 1969. In 1977, the country's name was changed to Socialist People's Libyan Arab Jamahiriya. Jamahiriya is a term coined by Gaddafi himself which is popularly translated as "state of the masses". The country was yet again renamed in 1986 to the Great Socialist People's Libyan Arab Jamahiriya. During the 1980s and 1990s, Gaddafi openly supported international terrorism as well as independence movements especially in Africa. He massively supported the African National Congress (ANC) of South Africa which eventually won independence for South Africa in 1994. He was equally a well-known supporter of the Palestinian Liberation Organization (PLO), Irish Republican Army (IRA) and the Polisario Front (PF). All these engagements led to Gaddafi being regarded in the International Community as an international terrorist whose views and actions were critically scrutinized with a lot of disdain and unbridled suspicion. It equally led to the country having unfriendly foreign relations with several countries of the world which came to a head with the United States bombing the country in 1986 which eventually led to a breakdown in diplomatic relationship between the two countries. The relationship between Libya and the United states was however normalized after the $9 / 11$ attacks.

The whole world will not forget in a hurry the Lockerbie bombing incident of 21 December 1988 of a Pan Am Flight. A bomb exploded during the flight and the fiery explosion which followed destroyed several houses and resulted in the death of 11 residents as well as 259 occupants of the plane who were citizens of twenty-one different nations. It was later revealed that Colonel Gaddafi personally gave the order for the Lockerbie bombing, an accusation Libya and Gaddafi denied for many years. However, in 2003, events took a new twist when Libya accepted responsibility for the Lockerbie bombing episode and agreed to pay compensation to victims' families.

\section{2011 Civil War and Collapse of Gaddafi's Government}

Despite the existential fact that life was relatively and averagely good for the masses in Libya under Gaddafi's long reign, one thing was lacking. It was freedom. Libyans were ruled with iron fists. They were gagged in so many aspects of life. It was obvious that Libyans lacked basic freedom. Freedom of association and that of expression were totally lacking in the country. Libyans lived in perpetual fear and Gaddafi's government never tolerated opposition of any sort. This was indeed the lowest point for the Gaddafi government while it lasted.

However, the events in sister North African countries of Tunisia and Egypt which led to the ouster of the draconian rules of Ben Ali of Tunisia and Hosni Mubarak of Egypt through people-oriented and implemented revolutions in these two countries must have encouraged Libyans so much to take their destiny in their own hands against Gaddafi's long and oppressive regime. The Libyan Civil War, one of the shortest ever fought in the continent of Africa was an armed conflict fought between forces loyal to Colonel Muammar Gaddafi, the self-styled saviour of the Libyan masses and those who sought to force him out of government. The war was preceded by protests in Benghazi which began 15 February 2011.

The protests escalated into a full blown rebellion that spread across the entire length and breadth of the country, with the rebels opposing Gaddafi's regime establishing an interim governing body named the National Transitional Council (NTC) led by Mustafa Abdul-Jalil. On 16 September 2011, the National Transitional Council was recognized by the United Nations as the legal representative of Libya, thus replacing the Gaddafi government on a permanent basis. The Security Council, an important organ of the United Nations passed a resolution on 26 February 2011, barely 11 days after the commencement of the Libyan civil war freezing the assets of Gaddafi and his inner-circle and restricting their movement. However, in March, forces loyal to Gaddafi rallied, pushed east wards and re-possessed several coastal cities before finally attacking Benghazi. In August, the National Transitional Council forces engaged the pro-Gaddafi forces in a coastal offensive and re-took most of their lost territories and captured the Capital City of Tripoli which was seen by the International Com- 
munity as a monumental achievement. Gaddafi managed to evade being captured when Tripoli fell and remained at large until 20 October 2011 when he was captured and killed in a fierce exchange of gun battle between troops of the National Transitional Council and forces loyal to his crumbling regime. Gaddafi fell to the fire power of the rebels while he was attempting to escape from Sirte. After the gruesome killing of Gaddafi, the National Transitional Council declared the liberation of Libya and also announced the official end of the Libyan Civil war on 23 October 2011.

\section{The Libyan Revolution: Its Philosophical Interpretations}

Philosophy remains a very germane discipline that has continued to remain very relevant over the centuries in human affairs. Philosophy therefore has continued to play a leading role in fashioning human activities. More often than not, human actions and inactions are interpreted from the stand point of philosophy as rational and irrational decisions mainly help to shape the universe either positively or negatively. It is in the light of the foregoing that this section discusses the philosophical interpretations of the Libyan revolution. This is very important as people's actions and even inactions affect not only themselves but the whole of humanity in general.

The Libyan revolution is one of the greatest revolutions that will be remembered in the history of the African continent for many years to come. The reasons for this assertion are not farfetched. First of all, Gaddafi was a well-known dictator who had an open disdain for opposition. He indeed spent a lot of time and huge Libyan resources monitoring his political opponents, making sure he handled them the way he deemed fit. Many of them he silenced for life while others he made to go through horrible, excruciating and horrendous tortures in order to weaken and silence them perpetually. Secondly, the living conditions in Libya were to a very large extent good and pleasurable by African standards hence by the mistaken calculation of Gaddafi and his cohorts, there was no need for the masses to take to the streets as they did. However, Gaddafi and his men got it all wrong. Gaddafi being clever by half gave Libyan citizens some measure of comfort but denied them freedom. When a man is denied his basic freedom, his humanity is indirectly called to question. This was what Gaddafi did to the Libyans for very many years. Libyans were not allowed the freedom to express themselves freely without being hounded like common criminals. Again, they were not allowed to form associations' especially political parties which could have afforded them the opportunity of having an organized platform to oppose Gaddafi's rule.

Freedom according to the Dictionary of Political Science (Chaturvedi, 2006: 123) is "the ability to think or acts one wishes, a capacity which can be associated with the individual, a social group or a nation". For The new International Webster's Comprehensive Dictionary of the English Language (2004: 503), freedom means the exemption or liberation from slavery or imprisonment. It is also exemption from political restraint or autocratic control. Between 2009 and 2011, Libya was rated as the most-censored state in the whole of North Africa and the Middle East. Dissent was illegal under Law 75 of 1973 and in 1974, Gaddafi asserted that anyone guilty of founding a political party would be executed (cf: Report of the Working Group on the Universal periodic Review: Libyan Arab Jamahiriya).

For a whole nation to have remained under the bondage of one hopeless dictator for 42 years is to say the least absurd, unbelievable and almost unthinkable. Indeed Gaddafi succeeded in reducing the Libyan state to a family affair keeping the country under the tight and firm grip of himself and his family members and had an unopposed opportunity of helping himself with the resources of the Libyan nation. He ostensibly made himself and his family members very rich at the expense of the Libyan citizens. Indeed, the wealth accruing to Libya as a nation from oil could have made more meaningful and direct impact on Libyans had it been judiciously and prudently managed. Unfortunately the reverse was the case.

Gaddafi's understanding of power and leadership is another disturbing issue. Gaddafi saw both concepts as being personal and should therefore be personalized hence he and his family could rule Libya for 42 years without ever thinking of the adverse effects such longevity in power could have on the social, economic and political pedestals of the country. For Nnoli (1986: 77) an adequate understanding of the concept of power is crucial for the comprehension of politics. In all sincerity, leadership should be a collective responsibility where people come in, play their part and give way so that other people can equally come in to make their own contributions too.

According to Ojukwu (2005: 18):

One essential demand of leadership is to be like a waste-paper basket, a dustbin where all dirt and rubbish are heaped. Whoever is not ready to accept such treatment does not qualify to be a leader. A leader must 
be prepared to have rubbish heaped on his head.

Perhaps what Ojukwu was referring to here was servant-leadership, a concept in leadership that Gaddafi and his cohorts were not ready to hear about let alone contemplate or even practice it. For Gaddafi, leadership was a personal issue.

\section{Lessons for Other Sit-Tight Leaders}

According to Nwala (2007: 74), "Each society contain within itself what it is and what it ought to be. The goals before it as well as the means for it to achieve these goals are immanent within the society". Africa as a continent has not been very fortunate as far as political leadership is concerned. It is the view of most scholars on Africa and Africa-related issues that its leaders in the various countries that make up the continent are squarely responsible for the sorry state in which the continent have found itself. Okolo (1994: 5-6) dwelt extensively on this. According to him:

The point is that the rallying views of many African intellectuals and political leaders particularly in the late fifties and sixties were that the cause rested squarely on Africa's former colonial masters and their continued overt and covert activities in the continent. However, there have been significant shifts in their views in recent years as several internal, social, political and economic combustions began to erupt in different African nations with coups, counter-coups, political assassinations, tribal wrangling, fratricidal wars, etc. One must not forget, too the calibre of such statesmen as Idi-Amin, Bokassa and Nguema and their record of leadership in Africa. It is increasingly the conviction of many today that the black man, rather, the African need not go beyond himself in search of the roots of his problems. The African condition is created by the African himself. He is his own enemy.

Perhaps one of the greatest problems that have plagued many African states since their independence till now is the inability of many African leaders both past and present to see politics and leadership as service. Indeed for many African rulers, politics is business and power is an opportunity for wealth acquisition. This accounts for the reason why many African politicians could go to any length to acquire power. They do so not necessarily to serve but to be served and to be liberated from the shackles of poverty that has afflicted them before they came to power. Once they grab power, it is used for personal aggrandizement and they can perpetuate all types of absurdities in order to retain it. They can change their countries constitutions with brazen impurity in order to go for third, fourth, fifth or even sixth tenures. They could come into power as military rulers through military coups and later transmute into civilian presidents.

In addition to Gaddafi who ruled his country Libya for 42 years, there are numerous other African leaders who have continued to perpetuate themselves in power even arbitrarily. Ben Ali of Tunisia ruled his country for 23 years before he was chased out of power this year, while Hosni Mubarak ruled Egypt for 30 years before he was also dethroned this year. Mobutu Sese Seko, Zaire's longest ruling dictator ruled his country for 31 years. Current sitting African dictators include Mbasago of Equatorial Guinea who has been in power since 1979, Jose Santos of Angola, who has also been in power since 1979. Robert Mugabe of Zimbabwe has been in power since 1980, while Paul Biya of Cameroon has been in power since 1982. The list is almost endless and the scenario is unfortunate for the continent of Africa.

Indeed, it is a very worrisome development in Africa. Many citizens of most African countries have virtually lost faith with the political and democratic processes in their countries. The reason for this is not far-fetched. According to Oguejiofor (2001: 35), "in a situation of incompetent, self-serving political leadership, corruption and embezzlement became so endemic that they have come to be regarded as normal".

The question is: can African leaders, especially those ones who have continued to perpetuate themselves in power learn from the misfortune of Gaddafi? Will they understand from now onwards that leadership is a collective responsibility and not a one-man-show? In the words of Okeke (2001: 107): "Government is an institution of the state. It is an agency or machinery through which the will of the state is formulated, expressed and attained". Indeed governance has become so problematic and polluted in Africa that people especially those of African descent have continued to devote much attention o it. According to Ekweke (2007: 13):

It is only necessary that we discuss one of the issues that is sufficiently problematic in today's Africa. This concerns the phenomenon of governing and the importance of he that is involved to be alive to the respon- 
sibility of this privileged exercise: an exercise that is necessarily predicated on service.

Almost re-echoing the same view, Fayemi (2006: 63) lamented:

It has almost becoming nauseating to recount Africa's problems: political instability, ethnic conflicts, bloody wars, permanent economic depression injustice and ugly faces of social disorder pervades the continent.

Perhaps the greatest lesson all sit-tight African leaders should learn from the misfortune of Gaddafi is that revolution is like a wild fire that can hardly be contained. They must realize that people are becoming increasingly aware of their rights and are ready to fight for these rights any time, any day. The clamour for democracy and good governance is becoming louder on daily basis in Africa and cannot be suppressed on the altar of dictatorship. It is the turn of Gaddafi today; it may yet be another person's turn tomorrow.

\section{Conclusion}

It is certainly not out of place to state that Libya as a nation was under the bondage of Gaddafi and his cohorts for forty two years. Indeed it was forty two agonizing years for millions of Libyan citizens who were brutalized and traumatized while thousands were killed for daring to oppose the "almighty" Gaddafi the "political messiah" of Libya.

However, since it is a truism that there is time for everything, the political uprisings in North Africa particularly in Egypt and Tunisia gave a lot of hope to the Libyan rebels that they can also stand up and be counted. Indeed, they took the bull by the horn, stoop up and were indeed counted. With the tacit support of the International Community, they were able to fight Gaddafi and his allies to a standstill despite the stiff opposition they mounted. The defeat and eventual murder of Gaddafi is a pointer to the age-long myth that those who make peaceful change impossible make violent change inevitable.

Perhaps, if Gaddafi had agreed to step down as he was advised, he would not have ended tragically like he did. Perhaps there could have been some atom of respect for a man that earned himself the title of the longest ruling African head of state. There is a great burden placed on the shoulders of the National Transitional Council (NTC) who are currently overseeing Libyan affairs as they have a herculean and daunting responsibility to rebuild Libya, a country that its former leader, Muammar Gaddafi helped to build while he was in power and at the same helped to destroy as a result of his inordinate ambition to hang on to power perpetually. Only time will tell whether they will be able to accomplish this onerous task or not. They have the golden opportunity of putting right in Libya what has gone wrong for the past 42 years. It is indeed a daunting responsibility. They cannot afford to fail. The world is watching with keen interest.

\section{References}

African Countries by GDP Per Capita > GDP per Capita (Most Recent) by Country. National Master. http://www.nationmaster.com/graph/eco.afr

Chaturvedi, A. K. (2006). Dictionary of Political Science. New Delhi: Oxford University Press.

Ekweke, E. E. (2007). Governance and Responsibility in Africa: The Nigerian Context. Amamihe Journal of Applied Philosophy, 5.

Fayemi, A. K. (2006). The Tragedy of Pseudo-Democracy and Social Disorder in Contemporary Africa: Any philosophical Rescue? In I. Odimegwu (Ed.), Philosophy and Africa. Amawbia: Lumos Nigeria Limited Global Edge (via Michigan State University) Undated. http://globaledge.msu.edu/countries/LibyanHistory/

Harrison-Barbet, A. (1990). Mastering Philosophy. London: The Macmillan Press Ltd. "Housing”.

Mautner, T. (2000). The Penguin Dictionary of Philosophy. London: Penguin Books.

Nnoli, O. (1986). Introduction to Politics. Lagos: Longman Nigeria a Limited.

Nwala, T. U. (2007). The Otonti Nduka Mandate: from Tradition to Modernity. Inaugural Lecture, Nsukka: University of Nigeria Press Ltd.

Oguejiofor, J. O. (2001). Philosophy and the African Predicament. Ibadan: Hope Publications.

Ojukwu, E. O. (2005). Because I Am Involved. Ibadan: Spectrum Books Limited.

Okeke, C. C. (2001). Introduction to Social Philosophy. Enugu: Academic Publishing Company. 
Okolo, C. B. (1994). Squandermania Mentality: Reflections on Nigerian Culture. Nsukka: University Trust Publishers.

Oladipo, O. (2007). On Philosophy. In T. Ebijuwa (Ed.), Philosophy and Social Change. Ibadan: Hope Publications. (Report of the Working Groups on the Universal Periodic Review: Libyan Arab Jamahiriya. United Nations Human Rights Council, United Nations General Assembly 4 January, 2011.)

Onigbinde, A. (2006). Philosophy and the Rest of Us. Ibadan: Frontline Books.

Onigbinde, A. (2009) What Is Philosophy? Ibadan: Frtontline Books.

The New International Webster's Comprehensive Dictionary of the English Language (2004). Florida: Trident Press International.

Wikipedia (2011). The History of Libya. http://en.wikipedia.org www.wikipedia.com/Nigeria 
Scientific Research Publishing (SCIRP) is one of the largest Open Access journal publishers. It is currently publishing more than 200 open access, online, peer-reviewed journals covering a wide range of academic disciplines. SCIRP serves the worldwide academic communities and contributes to the progress and application of science with its publication.

Other selected journals from SCIRP are listed as below. Submit your manuscript to us via either submit@scirp.org or Online Submission Portal.
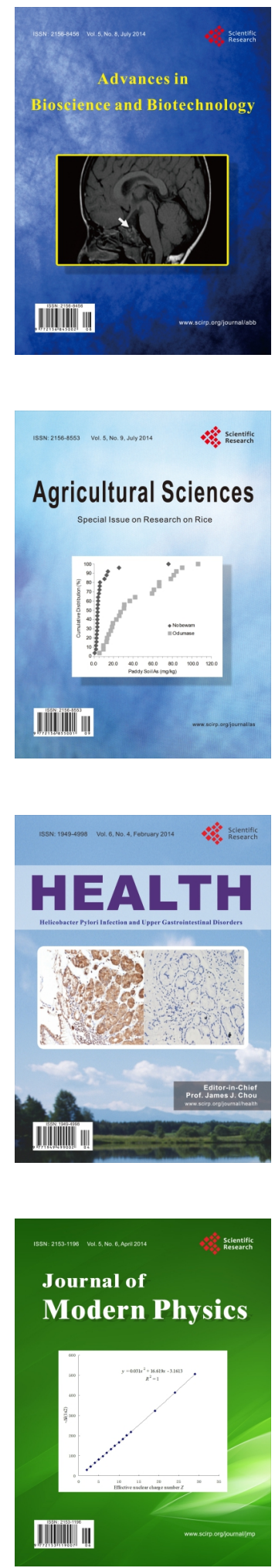
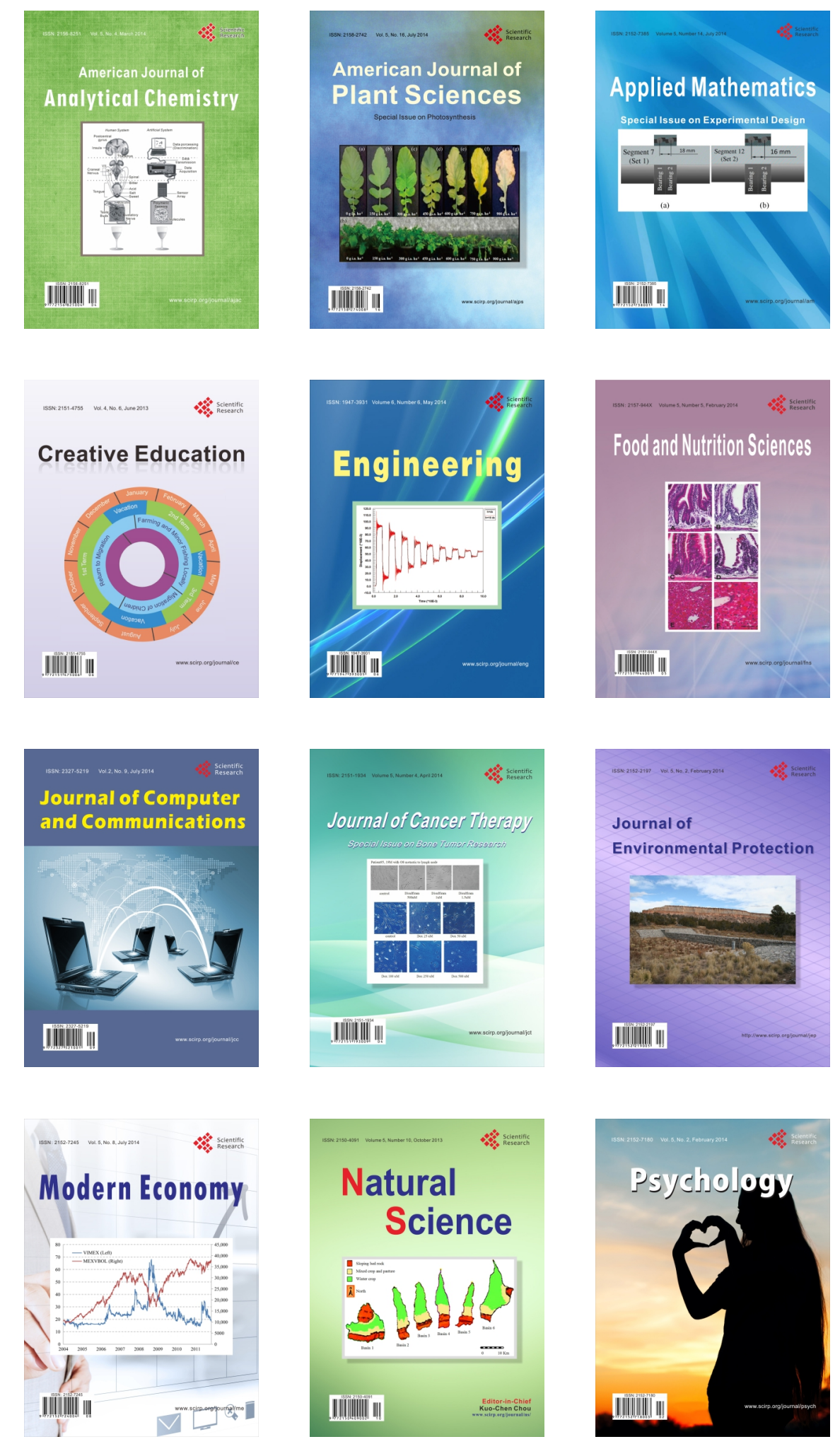